University of Nebraska - Lincoln

DigitalCommons@University of Nebraska - Lincoln

2013

Reviews of Science for Science Librarians: Drought in the Agricultural and Geosciences Literature

Leslie M. Delserone

University of Nebraska - Lincoln, Idelserone2@unl.edu

Adonna Fleming

University of Nebraska - Lincoln, dfleming2@unl.edu

Follow this and additional works at: https://digitalcommons.unl.edu/libraryscience

Part of the Climate Commons, Library and Information Science Commons, and the Meteorology

Commons

Delserone, Leslie M. and Fleming, Adonna, "Reviews of Science for Science Librarians: Drought in the Agricultural and Geosciences Literature" (2013). Faculty Publications, UNL Libraries. 296.

https://digitalcommons.unl.edu/libraryscience/296

This Article is brought to you for free and open access by the Libraries at University of Nebraska-Lincoln at DigitalCommons@University of Nebraska - Lincoln. It has been accepted for inclusion in Faculty Publications, UNL Libraries by an authorized administrator of DigitalCommons@University of Nebraska - Lincoln. 
Published in Science \& Technology Libraries (2013) 32: 30-44. Copyright 2013, Taylor \& Francis. Used by permission. DOI: 10.1080/0194262X.2012.758551.

\section{Reviews of Science for Science Librarians: Drought in the Agricultural and Geosciences Literature}

Leslie M. Delserone and Adonna Fleming University of Nebraska-Lincoln Libraries, Lincoln, Nebraska

Drought is a "hot" topic, given the climatic events of summer 2012 in the United States. This article provides a fundamental understanding of drought-its definitions, classifications, ratings, and impact on agriculture. Also included are introductions to drought-related research areas in the geosciences - specifically geology, hydrology, and atmospheric sciences - as well as pointers to reliable sources of information about drought from the agricultural and geosciences literature.

KEYWORDS: drought classification, drought metrics, drought indices, agricultural impact, paleoclimatology, geologic hazards, hydrology, National Climatic Data Center, National Drought Mitigation Center, United States Drought Monitor, El Niño-Southern Oscillation (ENSO), La Niña, Atlantic Multidecel Oscillation (AMO)

\section{INTRODUCTION}

News from the Midwest of the United States during the summer of 2012 discussed drought conditions and analyzed impacts on plant and animal production, as well as human activities. For example, in mid-July, the Los Angeles Times cited severe to exceptional drought conditions in more than 50 percent of the central states (Hennessy-Fiske 2012). According to the National Oceanic and Atmospheric Administration's (NOAA) National Climatic Data Center, at the end of July 2012, 86 percent of the "primary

Address correspondence to Leslie M. Delserone, Assistant Professor, University of Nebraska-Lincoln Libraries, Lincoln, Nebraska, USA; ldelserone2@unl.edu. 
corn and soybean belt" reported drought conditions so severe that only the droughts of the 1930s and 1988 were worse (NOAA National Climatic Data Center 2012). This was not the only region of the United States impacted by drought that summer - reports of dry conditions ranged from Hawaii to the Northeast (NOAA National Climatic Data Center 2012). The drought emergency continues at the time of this article's submission. The U.S. Drought Monitor for November 20, 2012, reported that 84.32 percent of the High Plains (the Dakotas, Nebraska, Kansas, Colorado, and Wyoming) are experiencing severe to exceptional drought; 98.80 percent of the region reported some drought condition (National Drought Mitigation Center 2012). It is typical for drought conditions to manifest in the United States annually, given the country's area and its varied climates (Wilhite 2005). However, statements reported by newspapers and NOAA mask the complications of defining the onset and end of drought, in drought classifications and metrics, and in relating modern drought episodes to human-induced climate change.

Records of drought and humankind's response to it appear in early written records and in geological history. For example, the Tractate $T a^{\prime}$ anit (a volume of the Babylonian Talmud, 1-6 C.E.) captures a religious interpretation of drought. Because rain is "a powerful symbol of God's presence," so, correspondingly, "drought [is] the essential expression of divine absence" (Belser 2009, 219-20). Anthropologists and archaeologists hypothesize that the prolonged drought of 1130-1150 C.E. in the southwestern United States is a key reason for the abandonment of many Anasazi settlements. An evaluation of climatic and other geological data led Benson, Petersen, and Stein (2007) to support this hypothesis. As described in the section Drought and the Geosciences, geologists have methods and techniques to study historical records and paleoclimatic occurrences of drought. Tree rings, peat land and lake bed sediments, rocks, and even ice sheets show evidence of droughts lasting for several decades (megadroughts) in the Earth's past (Kallis 2008; Mishra and Singh 2010). Analyses of historical climatic data also contribute to an understanding of drought's impacts in the past.

How do researchers define "drought"? There is no consensus definition, with the variations reflecting the disciplinary background of the researcher (Kallis 2008; Wilhite 2005). Renowned expert Donald A. Wilhite (2005, 338) described drought as "an insidious natural hazard that results from a deficiency of precipitation from expected or 'normal' that, when extended over a season or longer period of time, is insufficient to meet the demands of human activities." He emphasized that a meaningful definition, one applicable by those planning for and acting during drought situations, is associated with a region, impact, or application. Kallis $(2008,86)$ extended Wilhite's "conceptual" definition to attribute some or all of the lack of 
precipitation to "abnormal climate conditions," and included the criterion of "damaging [impacts] to an activity, group, or the environment." Mishra and Singh $(2010,205)$ pointed out that these conceptual definitions differ from "operational" definitions, which "can be used to analyze drought frequency, severity, and duration for a given return period." Many operational definitions exist, based on a particular variable (e.g., precipitation deficit, crop loss) and created by scientific researchers, professional, or nongovernmental organizations. For example, a report from the World Meteorological Organization (Monacelli 2005, 8) discussed "comparing the current situation to the historical average, often based on a 30-year period of record (according to World Meteorological Organization recommendations)."

In an additional refinement of operational definitions, researchers classify droughts as meteorological, agricultural, hydrological, or socioeconomic (Mishra and Singh 2010; Wilhite 2000, 2005). Kallis (2008) renamed "socioeconomic drought" as "water supply drought"; Mishra and Singh (2010) proposed a fifth classification, "groundwater drought." Descriptions of these categories appear in the following section, Classifications of Drought. But it is valuable to point out Kallis's (2008) insight that these classifications help to delineate the differing causes and timescales of events termed drought. Kallis $(2008,87)$ also emphasized that ". . . in a sense, all droughts that we humans care about are socioeconomic," not to dismiss the label but to urge the immediate application of current knowledge toward drought planning and mitigation.

Another ambiguous area of drought research is the inability to accurately determine a drought event's beginning and end. Wilhite (2005) attributed this lack of certainty to at least two factors - the slow onset and long-term cumulative effects of drought and the missing consensus definition that obscures determination of onset and severity. Whitmore (2000) concluded that it is only upon historical review that a drought's beginning and end become clear. However, there is a good understanding of the meteorological conditions that favor the development of drought (see Drought and the Geosciences section).

This discussion provides a broad, basic overview of the topic of drought, with emphasis on the United States, but does not attempt to address drought prediction, planning, and mitigation. While acknowledging the interdisciplinary nature of drought research and its wide-ranging impact, the authors choose to focus on agricultural impacts, geosciences research, and reliable sources of relevant agricultural and geosciences information.

\section{CLASSIFICATIONS OF DROUGHT}

Meteorological drought is a deficiency in normal precipitation for a specific region for a specific period of time (Heim 2002; Wilhite 2005). Weath- 
er and climatic conditions are regional phenomena. Researchers evaluate precipitation data on a monthly basis or may correlate deficits with the severity and impact of drought (Mishra and Singh 2010).

Agricultural drought describes a lack of soil moisture, associating meteorological drought's precipitation deficit with an impact on crop productivity (Heim 2002; Wilhite 2005). Mishra and Singh (2010) pointed out that this classification does not consider or account for any surface water contributions. As a result, agricultural drought joins atmospheric conditions (lack of precipitation) with plant and soil phenomena: evapotranspiration, water evaporation from the soil plus plant transpiration (U.S. Geological Survey 2012); crop physiology, the growth stage of the plants; and absent soil water (Mishra and Singh 2010; Wilhite 2000, 2005). Researchers analyze agricultural drought by looking at variables such as precipitation, soil moisture, and ambient temperatures (Mishra and Singh 2010).

Hydrological drought describes deficits in water resources other than precipitation; these include groundwater, streams, reservoirs, and lakes (Heim 2002; Kallis 2008). Geology, particularly as it influences streamflow, has the major impact on this category of drought (Mishra and Singh 2010). Hydrological drought usually is not synchronous with meteorological or agricultural droughts (Kallis 2008; Wilhite 2005).

Socioeconomic drought (Kallis's [2008] water supply drought) - the condition where water supply does not meet the demand from human activities - overlaps with the three drought classifications described above (Heim 2002; Wilhite 2005). The water deficiency is weather related, specifically a lack of precipitation (Mishra and Singh 2010). Impacts on human activities can range from water and power supply (e.g., hydroelectricity) to the production of various agricultural commodities (e.g., hay, feed grains) to human recreation (e.g., boating, swimming).

Groundwater drought (Mishra and Singh 2010) describes a longer-term situation of deficits in the groundwater system. Further discussion of this newer classification appears in the Drought and the Geosciences section.

\section{DROUGHTS DIFFER IN OTHER WAYS}

In addition to the categories presented above, droughts may differ in intensity, duration, and area affected; the combination of these three characteristics determines drought severity (Kallis 2008; Wilhite 2005). Intensity (the water deficit in the context of the historical record) and duration are interwoven attributes, as an abnormal deficit is obvious due to its length of occurrence (Kallis 2008). The spatial coverage ofa drought, the area sharing a given drought intensity, frequently changes during the event. Examination of the animated maps available at the U.S. Drought Monitor site (http:/ / droughtmonitor.unl.edu/) provides a vivid illustration of this characteristic. Kallis $(2008,86-87)$ refined the characteristics that dif- 
ferentiate droughts beyond the three mentioned above; he considered the "timing" and "effectiveness" of precipitation, the presence or absence of "hydroenvironmental factors, [i.e.,] soil, ... snowpack, or aquifer storage," and water's use (i.e., agricultural versus municipal).

\section{DROUGHT METRICS}

Given drought impacts, it is important to find a way to measure these events, in order to monitor drought development and to collect data for comparisons of drought events. The preceding discussion details issues with the definitions and classifications of drought. Just as there is no consensus operational definition, there is no single drought metric (Kallis 2008). Drought indices generally use precipitation, at a minimum, as a criterion to measure drought; other indices may have a hydrological emphasis as well (Kallis 2008; Mishra and Singh 2010). Several review articles have presented extensive listings and descriptions of the many indices developed and applied since the early twentieth century (Heim 2002; Kallis 2008; Mishra and Singh 2010). A partial listing of the indices covered by these reviews, loosely arranged in an increasing order of complexity, includes the following:

- days of rain

- Rainfall Anomaly Index

- National Rainfall Index

- percent of average rainfall (runoff or streamflow)

- Standardized Precipitation Index (SPI)

- deciles

- Palmer Drought Severity Index (PDSI)

- Reclamation Drought Index

- $\quad$ Soil Moisture Drought Index

- Crop Moisture Index (CMI)

- Crop-Specific Drought Index, subdivided into a Corn Drought Index,Soybean Drought Index, and Vegetation Condition Index (VCI)

- total water deficit

- days of supply remaining

- Surface Water Supply Index

- Objective Blend of Drought Indicators (OBDI)

Basic explanations for six of the most frequently applied indices follow.

The SPI is a straightforward measurement; its only variable is precipitation. The timescale for computation of the SPI is flexible, leading to its use to measure agricultural (i.e., soil moisture) and hydrological (i.e., groundwater, streamflow) deficits (Mishra and Singh 2010; Newman and Oliver 2005). However, its appropriate application requires a lengthy record of precipitation for a particular location and timeframe (Kallis 2008). 
The PDSI is a more complex index than the SPI; its use for several decades to monitor droughts supports its validity (Mishra and Singh 2010). The index measures precipitation and temperature in order to estimate moisture deficits in a given water supply and demand situation for a particular location and time frame (Newman and Oliver 2005). Precipitation is the primary water supply variable in PDSI. Water demand includes evapotranspiration, soil recharge (replenishment of water) needs, and runoff amounts needed for streams and other stored water resources (Kallis 2008; Newman and Oliver 2005). The index values allow for comparisons across climatic zones, primarily those ofthe American Central and High Plains states (Kallis 2008; Newman and Oliver 2005). The best use of the index is in agricultural scenarios due to its estimations of soil moisture deficits and their impacts; it is less effective in assessing hydrologic droughts (Mishra and Singh 2010; Newman and Oliver 2005).

The CMI (developed by W. Palmer of the PDSI) is most applicable in agricultural drought situations, calculating weekly moistures based on weekly temperatures and precipitation (Heim 2002; Mishra and Singh 2010). Unlike the PDSI, the CMI favors the most recent weekly data. As a result, this index can fluctuate weekly, but it is also more sensitive to moisture changes than the PDSI (Newman and Oliver 2005).

The VCI uses satellite data (visible and near-infrared) as a representation of vegetation condition, after adjusting for ecology, land, weather, and climate (Kallis 2008). Like the CMI, the VCI is most useful during the growing season (Mishra and Singh 2010). It is effective in "seeing" the earliest stages of a drought, in terms of vegetative impact, and in following the drought's development and severity. The VCI is a valuable tool for areas such as Africa, which may not have equipment available for hydrological or precipitation determinations. However, a major limiter of the VCI is that other factors affect vegetative condition besides drought, factors not distinguished by the satellite data (Kallis 2008; Mishra and Singh 2010).

As the previous summaries show, every index has limitations. Researchers often use more than one index to gauge a drought. There are ways to compare the values generated by different indices, usually by a conversion of the values to a frequency distribution. The OBDI, used by the U.S. Drought Monitor, is a percentile value (Kallis 2008).

U.S. Drought Monitor (http:/ / droughtmonitor.unl.edu/about.html), reported weekly, is an internationally respected combination of indices and impact interpretations. Kallis $(2008,89)$ noted that "... the Monitor provides data for OBDI, PDSI, SPI, VCI, a crop moisture index, the percentage of normal rainfall, daily streamflow, snowpack, and soil moisture for each of the climate divisions of the United States [and] synthesizes this information into an overall drought assessment of five severity levels. Levels relate to different indicator values and their historical probability of oc- 
currence." The five severity levels are as follows: D0, abnormally dry; D1, drought-moderate; D2, drought-severe, expected 5 to 10 years out of 100; D3, drought-extreme, expected 2 to 5 years out of 100; and D4, droughtexceptional, expected less than 2 years out of 100 (Kallis 2008; National Drought Mitigation Center 2012). There is a collective authorship and peer review of the weekly report. Each director of a U.S. meteorological agency serves a term as the lead author, with review by the other directors and researchers. Other scientists contribute important locale-specific data to the final map release and written report (Kallis 2008).

\section{DROUGHT AND CLIMATE CHANGE}

In a review of post-2000 publications for this discussion, there is documentation of a growing consensus among scientists that climate changewhether human induced and/or part of a natural cycle-is underway (Seager, Naik, and Vogel 2012). A possible consequence of global warming is an increase in extreme atmospheric events, including droughts (Kallis 2008; Mishra and Singh 2010). The literature reflects significant changes in majority scientific opinion about the connection between drought and global warming. In 2000, Whitmore (1) wrote, “... as droughts have recurred throughout recorded history, there is little need to attribute them to global warming or a hole in the ozone layer. While the causes of drought are still debatable, the scourge has been around for aeons of time." Five years later, Wilhite $(2005,338)$ took a strong opposing position: "The results from scientific investigations indicate that the frequency and severity of drought may increase for some regions in the future as a direct result of increasing concentrations of greenhouse gases in the atmosphere." Despite Wilhite's assertions, many researchers cite the lack of quantitative data to support a cause-and-effect relationship between climate change measures/predictions and drought (Kallis 2008; Mishra and Singh 2010). Peterson, Stott, and Herring (2012) explained that scientific analysis of the causes of current extreme events, such as droughts, has limits. However, they stated that a scientist may legitimately suggest a cause for drought, such as human-induced global warming, with appropriate recognition of the probabilistic nature of the explanation.

\section{DROUGHT AND AGRICULTURE}

Drought impacts are economic, environmental, and/or social; in addition, a drought's impact may be either direct or indirect (Wilhite 2005). Recent pictures ofdesiccated corn plants and cracked, parched soils in the U.S. Midwest illustrate that agricultural production takes a significant direct economic impact from drought conditions, particularly crops and pasture. Rangelands also suffer damage. Ding, Hayes, and Widhalm (2011, 436) noted that economic impact "... depends on the market structure and 
interaction between the supply and demand of agricultural products." Farmers may or may not suffer economic losses during a drought. If the drought leads to higher commodity prices, a grower with a commodity to sell may do well. Likewise, some farmers carry crop insurance that may compensate for some loss. Drought also affects pasture and other perennial crops, especially those needed for animal agriculture. Currently, there is a large-scale sell-off of livestock animals in the United States because of the cost and/or lack of hay, other forage, and feed grains. There likely will be a negative impact in 2013 on beef, pork, and chicken availability and higher prices for the American consumer (Robertson 2012). Smaller herds and increased consumer costs in 2013 may be a "lagged," negative effect of the drought of 2012 (Ding, Hayes, and Widhalm 2011, 437).

\section{DROUGHT AND THE GEOSCIENCES}

The study of drought is an interdisciplinary field involving scientists and researchers from a variety of backgrounds. The fields within the geosciences that study drought are geology, hydrology, and atmospheric sciences. Geologists primarily contribute to the study of drought in the areas of paleoclimatology, geologic hazards, and geohydrology.

The discipline of paleoclimatology focuses on past climates. It focuses on the study of droughts that occurred before instruments such as thermometers, rain gauges, barometers, and anemometers were available. Instead, geologists look at tree rings, lake and dune sediments, historical documents, archaeological remains, and other environmental indicators (NOAA Paleoclimatology Program 2003). Tree rings allow geologists to extend the available climate data from three hundred to ten thousand years before the present day. Tree rings map the annual growth of a tree, being more robust during moist periods compared to dry. These data, called "proxy data," are compared to the data collected during the twentieth century using instrumentation. Scientists use the extended time period to look for patterns and build models to predict the length and severity of future droughts.

Continuing back in time, geologists study lake sediments and sand dunes for evidence of drought. Lake sediments give a variety of clues. Lake level fluctuations are evident in the "bath tub rings" of beach materials left behind. Geologists determine periods of high water, indicating wet conditions, by measuring how far the bath tub ring of sediments is from the center of the lake. Lake sediments also indicate past climate in pollen counts from the rock cores drilled from the lake, because different vegetation grows during different climatic conditions. For example, grass is an indicator of wet periods, whereas sage is a marker of dry (NOAA Paleoclimatology Program 2003).

Sand dunes also provide past climatic evidence. Rock cores drilled from ancient sand dunes have layers of sand interspersed among layers of soil, 
with the soil indicating periods of wet conditions. Using these sediments, geologists are able to extend the available climate data back to ten thousand years before the present day (NOAA Paleoclimatology Program 2003). Geologic hazards are the effects of geology on humans. In some cases, these produce catastrophic results. Volcanoes and earthquakes that kill or affect large human populations in short periods of time are examples of catastrophic events, whereas droughts, which are slow acting, may lead to famine and desertification (Kusky 2003).

Geologic hazards resulting from drought include the advance of sand dunes onto farmland, the loss of top soil due to wind erosion, and landslides caused by slope instability due to decreased soil moisture or lack of vegetation. The Dust Bowl of the 1930s is an example of a drought with catastrophic consequences. Paleo-data indicate that anomalies in the Pacific Ocean temperature and upper atmospheric wind currents, known as ElNiño, contributed to the drought. ElNiño affects the climate in North America periodically, causing periods of dry weather during the growing season in the Midwest. In the 1930s, conditions were exacerbated by the plowing methods used at the time. As a result, huge dust storms occurred, forcing large numbers of the population to abandon their Midwestern farms for the West Coast (Kusky 2003).

Hydrology, the study of the Earth's water, is a vast field that looks at the chemistry, movement both above and below the surface, abundance, as well as the management and planning of water resources. This article focuses on geohydrology, the study of groundwater. Scientists study groundwater systems and drought impact by looking atgroundwater levels, although other factors, such as irrigation, can have an effect. Mishra and Singh (2010) listed groundwater drought as a new classification of drought and confirmed the need for further research on the relationship of drought and groundwater. They discussed the difficulty in determining the amount of available water in a groundwater system given the complexity of recharge.

Like other droughts, groundwater droughts occur when a lack ofprecipitation causes low recharge of water to the hydrologic system. This system consists of three layers: surface water, a zone where the water is unsaturated, and a saturated zone where water collects. The overall effects of a groundwater drought may be far reaching: from the decrease of water to riparian areas, springs, and streams to crop reduction and well yields, and occur on a timescale of months to years (Mishra and Singh 2010).

Depletion of a groundwater source, such as an aquifer, occurs naturally and/or by human intervention. Lack of recharge depends on not only precipitation deficits, but on stream and river migration or a geologic event (i.e., an earthquake) that cuts off a contributing water source. Humans deplete a groundwater source by extracting more water than is added. 
Activities such as irrigation, well drilling, and dam building and removal affect groundwater levels. Ironically, as a drought continues over time, humans rely more on groundwater to sustain crops and livestock, as well as municipalities, and the amount of time to recharge the groundwater extends to well after precipitation resumes (Bryant 2005).

Scientists study groundwater using trace isotopes and remote sensing. Trace isotopic analysis determines how long the water has been there and where it came from. Geophysicists use remote sensing to study location, extent, and depth of a groundwater resource.

Atmospheric sciences, the study of weather and climate, are a vast field with much of the research currently focused on human-induced global warming and climate change. The authors chose to focus on naturally occurring atmospheric events that contribute to drought.

Oceanic currents and temperatures and upper atmospheric wind directions determine weather patterns. Hadley cells are the belts of warm moist air that rise along the equator and move northward and southward depending on the seasonal position of the sun. As these cells move northward over the mid-latitudes, they mix with cold polar air moving southward. In the belts between the polar front and the Hadley cells, strong westerly winds develop. The polar jet stream controls the position of the polar front and the extent of the west-moving wind. Slight changes in the jet stream's path, called Rossby waves, determine high- or low-pressure systems. High pressure produces clear skies, whereas low pressure results in wet conditions. When this pattern changes significantly for a season or longer, storm systems may move over different areas, causing local floods or drought conditions (Kusky 2003).

Oceanic currents and temperature have a global influence on weather and climate. Three anomalies in normal ocean current and temperature patterns that influence the climate in North America are the El Niño-Southern Oscillation (ENSO), La Niña, and the Atlantic Multidecel Oscillation (AMO). When the ENSO system is in effect in the equatorial Pacific, changes occur in the weather systems in the mid-latitudes and can affect the climate across North America. During a period when El Niño is prevalent, ocean temperatures in the equatorial Pacific are unusually warm. Increased rainfall occurs across the southern tier of the United States, with atypically warm conditions from Alaska south through southwestern Canada and eastward to the Great Lakes. The opposite occurs during La Niña, when unusually cold ocean temperatures occur in the equatorial Pacific. Drought conditions become likely across the southwestern and southeastern United States. During La Niña, the northwestern United States has unusually wet winters. Likewise, cool conditions persist from Alaska to western Canada and across the northern United States (NOAA Paleoclimatology Program 2003). 
Research indicates that the AMO also influences climate in North America. Studies show that when the ocean temperatures in the north Atlantic are warmer than usual, droughts in the Midwest and Southwest tend to be more severe and frequent (NOAA Atlantic Oceanographic and Meteorological Laboratory 2005). Feng, Hu, and Oglesby (2011) discussed in detail the relationship between AMO and drought in North America. Using present conditions and paleo-proxy data, they were able to reconstruct climate conditions back to 1567 C.E. and determined that anomalies in the AMO have been a major influence on droughts in the Midwest and Southwest. The NOAA Atlantic and Meteorological Laboratory (2005) presents additional information about the AMO.

\section{INFORMATION SOURCES}

\section{Agriculture}

There is a range of sources by which to discover literature and data for those interested in drought and its impact on agriculture, including a number of reliable resources freely available on the Internet:

- National Drought Mitigation Center (http://drought.unl.edu/), based at the University of Nebraska-Lincoln, conducts research in drought management and policy. The Center's areas of research are climate-based monitoring, GIScience and analysis, and planning and social science. The website has information for both professionals and the interested public, including a "Drought for Kids" section. There are links to publications, including the fulltext of DroughtScape (quarterly newsletter), and a list of citations to research and scholarly publications, some of which are freely available via the University of Nebraska-Lincoln Digital Commons (http:/ / digitalcommons.unl.edu).

- U.S. Drought Monitor (http://www.drought.unl.edu/MonitoringTools/USDroughtMonitor.aspx), mentioned earlier, is a weekly report produced by the National Drought Mitigation Center, the U.S. Department of Agriculture, and NOAA. Animations, historical weather data, and other reports and data collections are available at this site. By clicking on a particular region of the U.S. map display, one can read more detailed regional severity information.

- The National Climatic Data Center (http://www.ncdc.noaa. gov/) is an archive of climatological data. It draws from historical records that existed only in print to the current day's digital data. The center publishes a monthly State of the Climate report, as well as an annual summary; the 2011 State of the Climate report is available at the site currently. Resources found under "Climate Infor- 
mation" are quite accessible, particularly "Climate at a Glance" and the "U.S. Drought Portal." Under "Support-Educational Resources" there are multimedia presentations available for teachers to use in class and for their continuing professional education.

- The National Agricultural Statistics Service (http://www.nass. usda.gov/) collects, distributes, and archives data and information relevant to U.S. agriculture. Crop Progress and Condition reports are just one example of available documentation about the impact of drought.

For freely available international information:

- The Food and Agriculture Organization of the United Nations (http://www.fao.org/index_en.htm) is a rich resource of information. Of particular interest is "Water," located under "Global Issues" (http://www.fao. org/nr/water/index.html). Both AquaMaps and AquaCrop provide access to data concerning global water resources and crop production.

- AgEconSearch (http://ageconsearch.umn.edu/) is a digital repository of white papers, conference reports, and scholarly journal articles in applied and agricultural economics. There is an international representation of research about drought and economic impact available here.

For citations to research articles, book chapters, books, and other materials:

- Agricola is an index provided by the National Agricultural Library (NAL). There is a publicly available interface at http://agricola. nal.usda.gov/, which includes the NAL catalog as well as an "Articles" search for journal articles and other agricultural information. Agricola also is available from commercial vendors, such as EBSCO, which provide links to full-text content where available.

- $\mathrm{CAB}$ Abstracts indexes an international pool of agricultural information, including drought impacts, from approximately 1973 onwards. This is a subscription service available from CABI (http:/ / www.cabdirect.org). The international coverage, particularly from non-English journals and gray literature, is excellent.

- GreenFILE (http://www.ebscohost.com/academic/greenfile) is an EBSCO multidisciplinary index that provides information about human impacts and interactions with the environment, including agriculture, drought, and other water-related issues.

\section{Geosciences}

- The NOAA web site (http://www.noaa.gov) offers a wealth of information about climate and weather. In particular, the site North American Drought: APaleo Perspective (http://www. 
ncdc.noaa.gov/paleo/drought/) is a good starting point for a novice researcher. The site offers a brief history of the discipline, describes how paleoclimatology is used in the study of droughts, discusses case studies in which paleoclimatic tools were used to gather data, has links to drought data sites, and provides a list of references for further study.

- The NOAA climate website (http://www.research.noaa.gov/ climate/) is a good place to start looking for information about climate including El Niño and La Niña, and lists several additional sites for more information. .The American Meteorological Society's website offers searching of all of their publications, including conference preprints (http://www.ametsoc.org/pubs/ index.html). The database yields results using the search terms: El Niño, La Niña, Atlantic Multidecel Oscillation, or their initialisms, drought, and North America.

To find additional references, the authors searched the GeoRef, Web of Science, and Water Resources Abstracts databases.

- GeoRef is the premier database for finding bibliographic citations for anything to do with the geosciences. It provides references to journal articles, books, government reports (including all publications of the U.S. Geological survey), maps, and theses and dissertations from U.S. and Canadian universities. Produced by the American Geophysical Institute, the database covers the geology of North America from 1669 and the rest of the world from 1933.

- Web of Science's Science Citation Index and the Social Science Index offer citations to peer-reviewed scholarly articles published from 1900 to present. There is some overlap between GeoRef and Web of Science. However, by including the Social Science Citation Index in a Web of Science search, the focus broadens beyond the geosciences. One will retrieve articles on the economic and human experiences of droughts. .Water Resources Abstracts covers both the technical and scientific literature on water-related topics from 1967 to present. A search of the index retrieves references on the use, management, and engineering aspects of water resources.

Hints for Searching Geological Indexes

When searching for bibliographic citations about the geosciences, the use of the geologic time period and location in the search is recommended. Specifically, the Holocene (ten thousand years before present day) should be used when searching for paleoclimatic research, because this is the time period when many clues to past climates were recorded in the Earth's stratigraphic record. 
In addition, when using GeoRef the use of geological terminology instead of layman or popular terms is recommended. GeoRef has its own thesaurus and classification codes for the major subdisciplines, which is useful in addition to subject search terms. These additional features can be found under the advanced search option on most GeoRef platforms.

To find references on paleoclimatology and drought, GeoRef and Web of Science were searched using the terms "Holocene," "paleoclimatology," and "drought." Locations, such as "North America" or "Great Plains", will further focus the results. Using the subdiscipline, such as dendrochronology or limnology, in a search with drought and a location is another approach.

Research articles on geologic hazards were found in GeoRef and Web of Science using the following search terms: "geologic or natural hazards," "drought," and a location such as "North America" or "Great Plains." For a more focused search, use the geologic subdiscipline geomorphology and the geologic term for the landform. For example, "Aeolian geomorphology" will retrieve citations about sand dunes; "karst geomorphology" will retrieve citations about sinkholes; and "slope instability," "debris flows," and "soil geomorphology" will retrieve citations about landslides. In another example, because deserts are a landform, the search phrase "desertification geomorphology" yields useful results from both GeoRef and Web of Science. Using the terms "desertification" and "effects" in the Social Citation Index produces a wide variety of results, ranging from effects on agriculture to human migration and government policies.

To find references on groundwater and drought, the three databases were searched using the following terms: "groundwater," "drought," and adding "effect," "recharge," or "discharge." Including a location further focuses the search. Searching for information about the effects humans have on groundwater during periods of drought, the databases were searched using the terms "groundwater management" and "drought." The GreenFILE database is also useful in finding articles on water management.

\section{SUMMARY}

Droughts are a regular occurrence in the United States, given the country's size and climatic variation. Many scientists expect that the intensity and duration of, and area affected by, drought will continue or increase due to global climate change. The references used in this discussion, as well as the web-sites and indexes discussed, point readers to reliable sources for themselves and those they serve.

\section{REFERENCES}

Belser, J. W. 2009. Crying out for rain: The human, the holy, and the Earth in the ritual fasts of rabbinic literature. Worldviews: Environment Culture Religion 13(2): 219-238. 
Benson, L., K. Petersen, and J. Stein. 2007. Anasazi (pre-Columbian Native-American) migrations during the middle 12th and late-13th centuries - Were they drought induced? Climatic Change 83: 187-213.

Bryant, E. 2005. Drought as a hazard. In Natural Hazards. 2nd ed., 103-119. Cambridge: Cambridge University Press.

Ding, Y., M. J. Hayes, and M. Widhalm. 2011. Measuring economic impacts of drought: A review and discussion. Disaster Prevention E Management 20(4): 434-446.

Feng, S., Q. Hu, and R. Oglesby. 2011. Influence of Atlantic sea surface temperatures on persistent drought in North America. Climate Dynamics 37: 569-586.

Heim, R. R. 2002. A review of twentieth-century drought indices used in the United States. Bulletin of the American Meteorological Society 83(8): 1,149-1,165.

Hennessy-Fiske, M. 2012. Drought expands, worsens; Midwest corn and soybean crops are at risk with hot, dry weather expected to last into August. Los Angeles Times, 20 July.

Kallis, G. 2008. Droughts. Annual Review of Environment \& Resources 33(1): 85-118.

Kusky, T. M. 2003. Deserts, drought, and wind. In Geological Hazards: A Sourcebook, 169-197. Westport, Conn.: Greenwood Press.

Mishra, A. K., and V. P. Singh. 2010. A review of drought concepts. Journal of Hydrology 391(1-2): 202-216.

Monacelli, G. 2005. Drought Assessment and Forecasting. Geneva, Switzerland: World Meteorological Organization. Available online at http://www.wmo.int/pages/ prog/hwrp/documents/regions/DOC8.pdf.

National Drought Mitigation Center. 2012. U.S. Drought Monitor: High Plains, November 20, 2012. Available at http://droughtmonitor.unl.edu/DM_highplains.htm.

Newman, J. E., and J. E. Oliver. 2005. Palmer index/Palmer drought severity index. In Encyclopedia of World Climatology, ed. J. E. Oliver, 571-73. Dordrecht, The Netherlands: Springer.

NOAA Atlantic Oceanographic and Meteorological Laboratory. 2005. FAQs about the AMO. Available at http://www.aoml.noaa.gov/phod/amo_faq.php.

NOAA National Climatic Data Center. 2012. State of the Climate | Drought | July 2012. Available at http://www.ncdc.noaa.gov/sotc/drought/2012/7.

NOAA Paleoclimatology Program. 2003. North American Drought: A Paleo Perspective. Available at http://www.ncdc.noaa.gov/paleo/drought.

Peterson, T. C., P. A. Stott, and S. Herring, eds. 2012. Explaining extreme events of 2011 from a climate perspective. Bulletin of the American Meteorological Society 93(7): 1,041-1,067.

Robertson, D. 2012. Hope dries up for America's ranchers. The Times (London), 10 September.

Seager, R., N. Naik, and L. Vogel. 2012. Does global warming cause intensified interannual hydroclimate variability? Journal of Climate 25(9): 3,355-3,372.

U.S. Geological Survey. 2012. The Water Cycle: Evapotranspiration, from USGS WaterScience School. Available at http://ga.water.usgs.gov/edu/watercycle evapotranspiration.html.

Whitmore, J. S. 2000. Drought Management on Farmland. Dordrecht, The Netherlands: Kluwer Academic Publishers.

Wilhite, D. A., ed. 2000. Drought: A Global Assessment. London and New York: Routledge.

Wilhite, D. A. 2005. Drought. In Encyclopedia of World Climatology, ed. J. E. Oliver, 338-341. Dordrecht, The Netherlands: Springer. 